\section{Transient hypothyroidism after iodine-131 treatment for thyrotoxicosis}

Many patients develop permanent hypothyroidism after being treated with iodine-131 ( $\left.{ }^{131} \mathrm{I}\right)$ for thyrotoxicosis and require replacement therapy with thyroxine. ${ }^{1}$ Transient hypothyroidism has been observed after subtotal thyroidectomy for thyrotoxicosis, ${ }^{2}$ but whether this phenomenon exists after ${ }^{131}$ I treatment is disputed. ${ }^{3}$ In 1977 we reported two cases of transient hypothyroidism after ${ }^{131}$ I treatment, since when we have seen a further eight cases, which we report here.

\section{Patients, methods, and results}

The patients comprised seven women, median age 52 years (range 49-69), and three men aged 50,59, and 67 years attending the thyroid clinic at this hospital. Thyrotoxicosis was confirmed biochemically and by an increased two-hour uptake of ${ }^{132} \mathrm{I}$. None of the patients were receiving antithyroid drugs, and all had diffuse thyroid enlargement. Doses of ${ }^{131} \mathrm{I}$ ranged from 2.5 to $11.8 \mathrm{mCi}$ (median $4 \mathrm{mCi}$ ). The diagnosis of transient hypothyroidism was based on a low serum thyroxine (T4) concentration. Serum T4, triiodothyronine (T3), and thyroid-stimulating hormone (TSH) concentrations were measured by radioimmunoassay. Normal ranges were: serum T4 $60-140 \mathrm{nmol} 1(4 \cdot 7-10 \cdot 9 \mu \mathrm{g} 100 \mathrm{ml})$, serum T3 $1 \cdot 2-2 \cdot 7 \mathrm{nmol}$ $(0.8-1.8 \mathrm{ng} \mathrm{ml})$, and serum $\mathrm{TSH}<6 \mathrm{mU} 1$. Statistical analysis included Friedman's two-way analysis of variance test and Wilcoxon's matched pairs signed ranks test.

The figure shows the serum concentrations of T4, T3, and TSH measured immediately before ${ }^{131}$ I treatment, when subnormal serum $T 4$ concentrations were first found, and when serum T4 concentrations were first noted to be normal again. No patient became clinically hypothyroid when the serum $\mathrm{T} 4$ concentration was transiently low.

After treatment the median serum $\mathrm{T} 4$ concentration decreased from $211.5 \mathrm{nmol} / 1(16.4 \mu \mathrm{g} / 100 \mathrm{ml}$ ) (range $160-320 \mathrm{nmol} 1 ; 12 \cdot 4-24 \cdot 9 \mu \mathrm{g} / 100 \mathrm{ml}$ ) to $38.5 \mathrm{nmol} / 1(3.0 \mu \mathrm{g} / 100 \mathrm{ml}$ ) (range $20-55 \mathrm{nmol} 1 ; 1 \cdot 6-4 \cdot 2 \mu \mathrm{g} / 100 \mathrm{ml}$ ) and then increased to $92 \mathrm{nmol} / 1(7 \cdot 1 \mu \mathrm{g} / 100 \mathrm{ml}$ ) (range $62-187 \mathrm{nmol} / 1 ; 4 \cdot 8-14 \cdot 5$ $\mu \mathrm{g} / 100 \mathrm{ml})$. Serum T3 concentrations fell from a median of $4.85 \mathrm{nmol}$

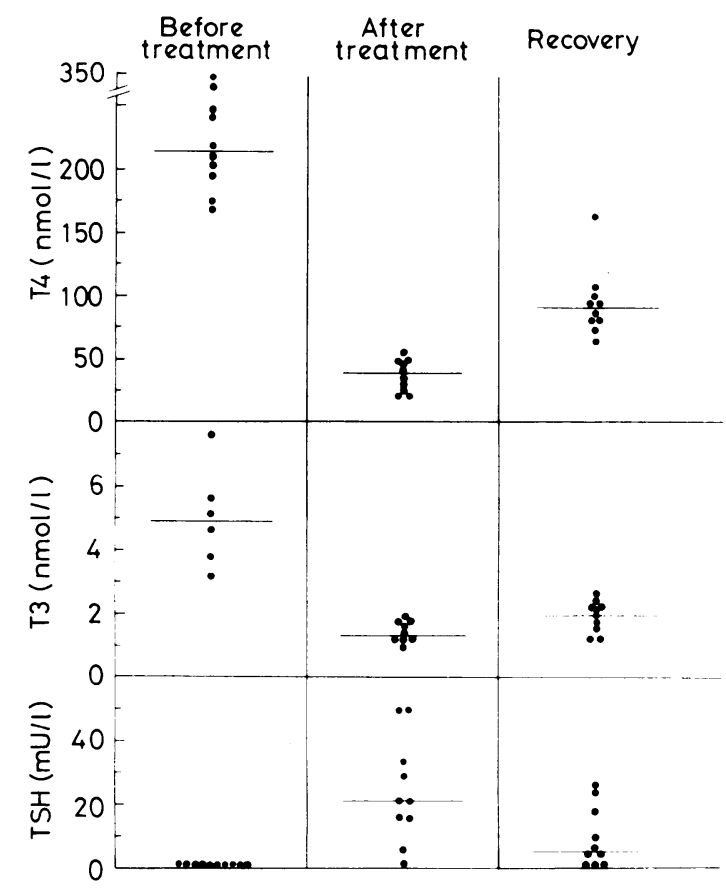

T4, T3, and TSH concentrations (with median) in 10 patients with transient hypothyroidism after ${ }^{131} \mathrm{I}$ treatment for thyrotoxicosis.

Conversion: SI to traditional units-T4: $1 \mathrm{nmol} 1 \approx 77 \cdot 7$ ng $100 \mathrm{ml}$. T3: $1 \mathrm{nmol} 1=0.65 \mathrm{ng} \mathrm{ml}$.
(3.2 ng/ml) (range $3 \cdot 1-7 \cdot 6 \mathrm{nmol} / 1 ; 2 \cdot 0-4.9 \mathrm{ng} / \mathrm{ml}$ ) to a median of $1.3 \mathrm{nmol} / 1$ $(0.8 \mathrm{ng} / \mathrm{ml}$ ) (range $1.0-1.9 \mathrm{nmol} / 1 ; 0.7-1.2 \mathrm{ng} / \mathrm{ml}$ ) and recovered to a median of $1.95 \mathrm{nmol} / 1(1.3 \mathrm{ng} / \mathrm{ml}$ ) (range $1.2-2.5 \mathrm{nmol} / 1 ; 0.8-1.6 \mathrm{ng} / \mathrm{ml}$ ). The median serum TSH concentration rose to $21 \mathrm{mU} / 1$ (range $<2-50+$ ) and then fell to $5.5 \mathrm{mU} / 1$ (range $<2-25$ ). There was a significant difference $(\mathrm{P}<0.0005)$ between each of the serum T4 and TSH concentrations obtained on the three occasions. Serum T3 concentration was estimated on the three occasions in only six patients, in all of whom there was a significant difference between each measurement $(P<0.0002)$. The low serum T4 concentrations were recorded from six to 24 weeks (median 12 weeks) after treatment, and the recovery concentrations from eight to 52 weeks (median 25 weeks)

The patients were followed up for seven months to four years (median 19 months), six for more than one year. Two of these six became clinically and biochemically hypothyroid after four years, requiring thyroxin treatment. Two had raised serum TSH but normal serum T3 and T4 concentrations and were clinically euthyroid, and two had normal serum TSH, T3, and $\mathrm{T} 4$ concentrations.

\section{Comment}

In seven of our patients low serum $\mathrm{T} 4$ concentrations were found within three months of ${ }^{131} \mathrm{I}$ treatment and had recovered by seven months. These changes were closely similar to those following subtotal thyroidectomy ${ }^{2}$ and were probably due to the same mechanisms-that is, a fluctuating titre of thyroid-stimulating immunoglobulins and delayed recovery of suppressed pituitary thyrotrophs. None of our patients became clinically hypothyroid during the transient depression of thyroid hormones, which is consistent with the findings that biochemical hypothyroidism during carbimazole treatment can precede clinical hypothyroidism by many weeks. ${ }^{5}$ Thus not all patients developing biochemical hypothyroidism soon after ${ }^{131}$ I treatment need to start lifelong thyroxine replacement therapy. Also, two of our patients now have mildly raised thyroid hormone concentrations, and thyroxine treatment in these patients may be harmful.

IAM was supported by a grant from the North-west Regional Health Authority. We thank Mr R Swindell for statistical advice.

1 Toft, A D, et al, Lancet, 1975, 2, 576.

2 Toft, A D, et al, Lancet, 1976, 2, 817.

${ }^{3}$ Toft, A D, and Irvine, W J, Lancet, 1977, 2, 1128

- Shalet, S M, MacFarlane, I A, and Beardwell, C G, Lancet, 1977, 2, 1357.

${ }^{5}$ Mortimer, C H, et al, British Medical fournal, 1977, 1, 138.

(Accepted 27 June 1979)

Department of Endocrinology, Christie Hospital and Holt Radium Institute, Manchester, M20 9BX

I A MACFARLANE, MB, MRCP, research fellow (present appointment: lecturer in medicine, Royal Infirmary, Manchester)

$S$ M SHALET, MB, MRCP, consultant endocrinologist C G BEARDWELL, MB, FRCP, consultant endocrinologist J S KHARA, MB, BS, senior house officer

\section{Is long-term immunosuppressive treatment necessary to maintain good kidney graft function?}

In most centres immunosuppression is regarded as essential after kidney transplantation. Long-term non-specific immunosuppressive treatment, however, may result in diabetes, hypertension, obesity, tumours, etc owing to an inappropriate and generalised suppression of host immune responses. ${ }^{1}$ During a study to evaluate the immunological states of patients with good renal function over three years after transplantation we found that one had stopped taking her immunosuppressive treatment. Her clinical and immunological state, however, was similar to that of the other patients. This suggested 